\title{
Inuloxins A-D and derivatives as antileishmanial agents: structure-activity relationship study
}

\author{
Fabiana Avolio ${ }^{1,2}$, Agnes M Rimando ${ }^{2}$, Alessio Cimmino ${ }^{1}$, Anna Andolfi ${ }^{1}$, Surendra Jain ${ }^{3}$, Babu L Tekwani ${ }^{3,4}$ \\ and Antonio Evidente ${ }^{1}$
}

The Journal of Antibiotics (2014) 67, 597-601; doi:10.1038/ja.2014.47; published online 30 April 2014

Leishmaniasis, which is manifested in different clinical forms, is a vector-borne disease caused by protozoan parasites belonging to the genus Leishmania. ${ }^{1}$ Although a majority of literature mentions only one genus (Lutzomyia) transmitting leishmaniasis to humans in the USA, elsewhere in the world the genus Phlebotomus is considered to be the vector of leishmaniasis. ${ }^{2}$ Female sand flies act as carriers of the parasite, and the parasite is transmitted from person to person or from a range of animals to humans. ${ }^{1}$ In fact, Leishmania species are widespread in 88 countries, affecting the visceral organs, skin and mucous membrane. ${ }^{3}$

Treatment options for leishmaniasis are very limited. Although studies have identified several antigens, as potential vaccine target, currently no vaccine against the disease is in routine use or in advanced stage of development. ${ }^{4}$ There are two common therapies under use, which contain pentavalent antimony. It is not completely understood how these drugs act against the parasite. These drugs induce severe adverse effects such as myalgia, anorexia, nausea, vomiting, lack of appetite, tremor, diarrhea, and fever. ${ }^{5}$ In many parts of the world, the parasite has become resistant to antimony when used in treating visceral or mucocutaneous leishmaniasis. ${ }^{6}$ Very few new drugs have been discovered $^{7}$ such as miltefosine, used for treatment of visceral and cutaneous leishmaniasis in different countries. This drug also has unwanted side effects, mainly gastrointestinal disturbance. ${ }^{8}$ In addition, there are problems associated with the use of miltefosine, being teratogenic and has unfavorable pharmacokinetic properties. ${ }^{6}$ The Institute for One World Health has reintroduced the drug paromomycin for treatment of leishmaniasis, on the basis of results which led to its approval as an orphan drug. A 21-day study using paromomycin produced a definitive cure in $>90 \%$ patients with visceral leishmaniasis. ${ }^{9}$ Drugresistant leishmaniasis may respond to immunotherapy (inoculation with parasite antigens plus an adjuvant), which aims to stimulate the body's own immune system to kill the parasite. However, the cost for this kind of treatment is prohibitive. ${ }^{10}$
There is continued interest in the search for a new drug for treatment of leishmaniasis. Natural substances of plant origin offer a wide source of untapped potential treatment agents. In this regard, we have tested five sesquiterpenoids, inuloxins A-D (1-4, Figure 1) and $\alpha$-costic acid (5, Figure 1), previously isolated from Inula viscosa (L.) Grueter, a perennial plant common throughout the Mediterranean Basin, for their activity against the leishmania parasite in culture. Inuloxins $\mathrm{A}-\mathrm{D}$, belonging to different subgroups of sesquiterpenoids such as germacrenolides, eudesmanolides and seco-eudesmanolides, have shown potential as safe natural herbicides for the biocontrol of parasitic plants including Orobanche and Cuscuta species. ${ }^{11}$ It was therefore considered of interest to investigate other biological activities for these compounds, as well as their hemisynthetic analogs. Derivatives of inuloxin A (6-10), C (11) and D (12) were prepared. Inuloxins $\mathrm{A}-\mathrm{D}$ and the derivatives, as well as $\alpha$-costic acid have also been tested for activity against some fungi (Candida albicans, Candida glabrata, C. rusie; Cryptococcus neoformans and Aspergillus fumigatus), bacteria (Staphylococcus aureus, methicilinresistant S. aureus, Escherichia coli, Pseudomonas aeruginosa and Mycobacterium intracellulare), and chloroquine-sensitive and resistant strains of the malaria parasite Plasmodium falciparum. These compounds did not have significant activity against the fungi, bacteria and the malaria protozoa (unpublished observations), and appeared to have selective activity against the parasite Leishmania donovani, the causative agent for visceral leishmaniasis. ${ }^{12}$ The hemisynthesis of inuloxin derivatives and structure-antileishmania activity relationship are reported here.

Reduction of inuloxin A with $\mathrm{NaBH}_{4}$ resulted in two diastereomeric derivatives 6 and 7 (Figure 2). The IR spectra of both 6 and 7 showed the presence of a hydroxy group band. The ${ }^{1} \mathrm{H}$ NMR spectrum of $\mathbf{6}$ differed from that of $\mathbf{1}^{11}$ in having a multiplet at $\delta$ 3.79 due to hydrogen (H-3) of the secondary hydroxylated carbon (C-3), and for the upfield shift ( $\Delta \delta 1.02$ and 0.94 p.p.m.) of the adjacent methylene protons $\left(\mathrm{H}_{2} \mathrm{C}-2\right)$, which resonated as a multiplet

${ }^{1}$ Dipartimento di Scienze Chimiche, Università di Napoli Federico II, Complesso Universitario Monte S. Angelo, Napoli, Italy; ${ }^{2}$ U.S. Department of Agriculture, Agricultural Research Service, Natural Products Utilization Research Unit, University of Mississippi, University, MS, USA; ${ }^{3}$ National Center for Natural Products Research, Research Institute of Pharmaceutical Sciences, The School of Pharmacy, University of Mississippi, University, MS, USA and ${ }^{4}$ Department of Pharmacology, The School of Pharmacy, University of Mississippi, University, MS, USA

Correspondence: Professor A Evidente, Dipartimento di Scienze Chimiche, Università di Napoli Fedreico II, Complesso Universitario Monte S. Angelo, Via Cintia 4, 80126 Napoli, Italy.

E-mail: evidente@unina.it

Received 5 November 2013; revised 18 March 2014; accepted 1 April 2014; published online 30 April 2014 
<smiles>C=C1C(=O)OC(CCCCCC)C1CC=CC</smiles>

1

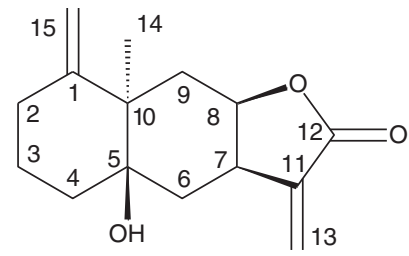

3<smiles>CC1=CCC2C(=O)CCCCCC2OC(=O)C(C)C1C</smiles>

2<smiles>C=C1C(=O)OC2CC(C(C)CC[C@@H](C)O)=CCC12</smiles>

4

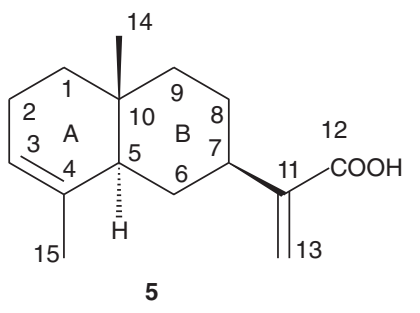

Figure 1 Structures of inuloxins (A-D) (1-4) and $\alpha$-costic acid (5).

at $\delta$ 1.50. Furthermore, the signals for the methylene group exocyclic at the lactone ring $\left(\mathrm{CH}_{2}-13\right)$ were absent, whereas the signals for the proton (H-7) of a secondary carbon and the methyl group (Me-13) were observed as a quintet $(J=7.6 \mathrm{~Hz})$ and as a doublet $(J=7.6 \mathrm{~Hz})$ at $\delta 2.78$ and 1.20 , respectively. Similarly, the ${ }^{1} \mathrm{H}$ NMR spectrum of 7 showed the multiplet due to $\mathrm{H}-3$ at $\delta 3.79$, the upfield shift of the $\mathrm{H}_{2} \mathrm{C}-2$ protons $(\Delta \delta 0.96$ and 0.88 p.p.m. from that of $\mathbf{1})$ appearing as multiplet at $\delta 1.56$, and the quintet $(J=7.2 \mathrm{~Hz})$ and the doublet $(J=7.2 \mathrm{~Hz})$ of $\mathrm{H}-11$ and Me-13 at $\delta 2.41$ and 1.22. The ESIMS spectra of both compounds, recorded in positive mode, showed the sodium adduct $[\mathrm{M}+\mathrm{Na}]^{+}$at $m / z 275$; when recorded in the negative mode the pseudomolecular ion $[\mathrm{M}-\mathrm{H}]^{-}$was observed at $\mathrm{m} / \mathrm{z}$ 251. The atmospheric pressure chemical ionization-MS (APCIMS) spectra also showed the pseudomolecular ion $[\mathrm{M}+\mathrm{H}]^{+}$, as well as the ion it generated by loss of water $\left[\mathrm{M}+\mathrm{H}-\mathrm{H}_{2} \mathrm{O}\right]^{+}$at $m / z 253$ and 235 , respectively.

The stereochemistry at C-11 of $\mathbf{6}$ and 7 was deduced to be the same as that of 2 based on the coupling constants between $\mathrm{H}-11$ and $\mathrm{H}-7$, and between $\mathrm{H}-11$ and $\mathrm{Me}-13$, which are the same as those for inuloxin B. ${ }^{11}$ Furthermore, the chemical shifts of H-7, H-11 and Me-13 were very similar to those of $\mathbf{2}$. The stereochemistry at C-3 was deduced as discussed below.

By usual acetylation with pyridine and acetic anhydride, both 6 and 7 were converted into the corresponding 3-O-acetyl derivatives 8 and 9, respectively. Their IR spectra showed the absence of the hydroxy group band and the presence of bands of the acetyl group. As expected, the ${ }^{1} \mathrm{H}$ NMR spectrum of $\mathbf{8}$ essentially differed from that of 6 for the downfield shift $(\Delta \delta 1.68)$ of $\mathrm{H}-3$ resonating as a broad triplet $(J=8.4 \mathrm{~Hz})$ at $\delta 5.47$ and for the presence of the singlet of the acetyl group at $\delta$ 2.02. Similarly, the ${ }^{1} \mathrm{H}$ NMR spectrum of 9 essentially differed from that of 7 for the downfield shift $(\Delta \delta$ 1.62) of $\mathrm{H}-3$ appearing as a broad double doublet $(J=8.0$ and $10 \mathrm{~Hz})$ at $\delta 5.41$ and for the singlet of the acetyl group at $\delta$ 2.05. Their ESI-MS spectra showed the sodium adduct $[\mathrm{M}+\mathrm{Na}]^{+}$and the pseudomolecular ion $[\mathrm{M}+\mathrm{H}]^{+}$at $m / z 317$ and 295 , respectively.

The 3-O-acetyl derivative $\mathbf{8}$ was used to carry out a NOESY experiment aimed to determine the stereochemistry at C-3 of both 8 and $\mathbf{9}$, and thereby also of $\mathbf{6}$ and 7. In the NOESY spectrum of 8 a correlation was observed between the methyl of the acetyl group and Me-15, instead in those of 9 this correlation was not observed. So that in 8 and 9 the acetoxy group was $\alpha$ - and $\beta$-located, respectively. The same stereochemistry was therefore assigned to C-3 of derivatives 6 and 7; the orientation of the hydroxy group is as depicted Figure 2.

Inuloxin A derivative $\mathbf{1 0}$ was prepared by reaction of $\mathbf{1}$ with diazomethane as detailed previously. ${ }^{11}$ Inuloxin C (3) was converted into the corresponding derivative 11 by methylene insertion using diazomethane (Figure 3a). Inuloxin D (4) was converted into the corresponding 4-O-acetyl derivative by usual acetylation (12, Figure $3 \mathrm{~b}$ ). The ${ }^{1} \mathrm{H}$ NMR spectrum of $\mathbf{1 1}$ differed from that of 3 by absence of the two doublets due to the protons of the exocyclic methylene group and the presence instead of four doublets of doublets of doublets due to the coupled methylenes $\left(\mathrm{H}_{2} \mathrm{C}-13\right.$ and $\mathrm{H}_{2} \mathrm{C}-16$ ) of the new dihydrofuran ring. The methylene proton resonances were observed at $\delta 4.78(J=10.0,9.6$ and $5.2 \mathrm{~Hz})$ and $\delta$ $4.64(J=10.0,8.4$ and $7.2 \mathrm{~Hz})$ for the protons at $\mathrm{C}-16$, and at $\delta 1.79$ $(J=15.0,8.4$ and $5.2 \mathrm{~Hz})$ and $1.69(15.0,9.6$ and $7.2 \mathrm{~Hz})$ for the protons at C-13. Its ESI-MS spectrum showed the sodium adduct $[\mathrm{M}+\mathrm{Na}]^{+}$and the pseudomolecular ion $[\mathrm{M}+\mathrm{H}]^{+}$at $m / z 283$ and 261, respectively. The IR spectrum of 12 showed the absence of hydroxy group band and the presence of bands due to the acetyl group. Its ${ }^{1} \mathrm{H}$ NMR spectrum essentially differed from that of $4^{11}$ for the downfield shift of $\mathrm{H}-4(\Delta \delta 1.06)$, which resonated as a multiplet 
<smiles>CC1=CCC2C(CCCC[C@@H]1O)OC(=O)[C@H]2C</smiles><smiles></smiles><smiles>CO[C@H]1CCCCC2OC(=O)[C@@H](C)C2CC=C1C</smiles><smiles>C=C1C(=O)OC2CCCCC(=O)C(C)=CCC12</smiles>

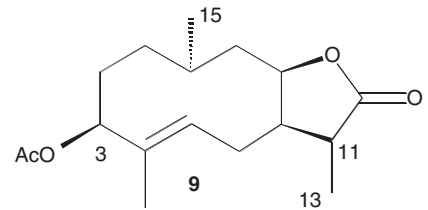<smiles></smiles>

Reaction conditions: a) $\mathrm{NaBH}_{4}, \mathrm{MeOH}$, rt, $2 \mathrm{~h}$; b) $\mathrm{Ac}_{2} \mathrm{O}$, pyridine, rt, $12 \mathrm{~h}$; c) $\mathrm{CH}_{2} \mathrm{~N}_{2}$ in $\mathrm{MeOH}$ rt $1 \mathrm{~h}$

Figure 2 Hemisynthesis of inuloxin A derivatives 6-10.

a<smiles>C=C1C(=O)OC2CC3C(=C)CCCC3(O)CC12</smiles><smiles>C=C1CCCC2(O)CC1OC1=C3C(C2)O[C@@H]3C1</smiles>

11

b

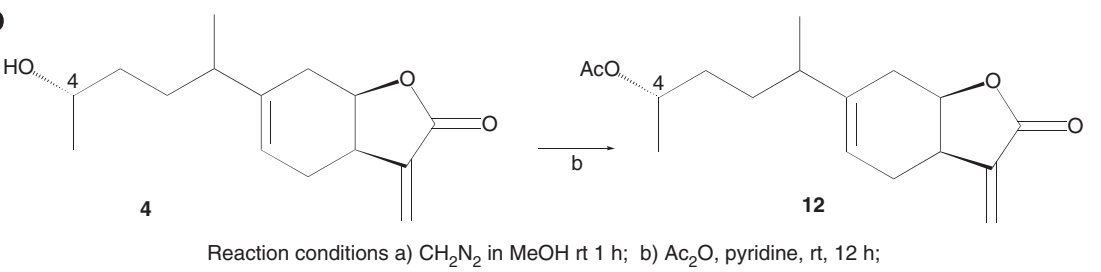

Figure 3 (a) Hemisynthesis of inuloxin C derivative 11; (b) hemisynthesis of inuloxin D derivative 12.

at $\delta$ 4.86, and for the presence of the singlet of the acetyl- $\mathrm{CH}_{3}$ group at $\delta$ 2.04. Its ESI-MS spectrum showed the sodium adduct $[\mathrm{M}+\mathrm{Na}]^{+}$at $m / z 315$.

The compounds were tested in vitro against promastigotes culture of L. donovani. Inuloxin A (1) showed activity against the leishmania parasite similar to the standard antileishmanial drug pentamidine, but was less active than amphotericin B (Table 1). Inuloxins C (3) and D (4) showed a slightly lower activity compared with 1 , whereas inuloxin B (2) and all the derivatives showed either weak antileishmanial activity or were completely inactive against the leishmania parasite. These results indicate that among the inuloxin compounds tested, the furanone ring is an essential structural feature important for the activity as reported for the antiprotozoal activity of some plant sesquiterpene lactones by Schmidt et al. ${ }^{13} \alpha$-Costic acid, which does not have the furanone ring, was found to be inactive. The partial structures linked to this ring, namely, octahydrocyclodecenone (in 1 and 2), decahydronaphtho (in 3) and tetrahydrobenzo (in 4) moieties are not critical for the antileishmanial activity. The presence of an exocyclic methylene group in the furanone ring appeared to be particularly important for the activity, because when it is saturated (as in inuloxin B, and the reduced diastereomeric derivatives 6-9, the antileishmanial activity was completely lost. This was also confirmed 
Table 1 In vitro antileishmanial activity of inuloxins A-D (1-4), $\alpha$-costic acid (5) and inuloxin derivatives (6-12) against Leishmania donovani

\begin{tabular}{lcc}
\hline Compound & $\mid C_{50}\left(\left.\mu g\right|^{-1}\right)$ & $\mid C_{90}\left(\left.\mu g\right|^{-1}\right)$ \\
\hline 1 & $1.71 \pm 0.31^{\mathrm{a}}$ & $4.7 \pm 0.52$ \\
$\mathbf{2}$ & $17.77 \pm 4.16$ & $>40$ \\
3 & $3.79 \pm 0.41$ & $6.18 \pm 1.11$ \\
4 & $3.89 \pm 0.26$ & $11.0 \pm 1.53$ \\
5 & $\mathrm{NA}$ & $\mathrm{NA}$ \\
6 & $\mathrm{NA}$ & $\mathrm{NA}$ \\
7 & $\mathrm{NA}$ & $\mathrm{NA}$ \\
8 & $34.68 \pm 3.13$ & $\mathrm{NA}$ \\
9 & $\mathrm{NA}$ & $\mathrm{NA}$ \\
10 & $\mathrm{NA}$ & $\mathrm{NA}$ \\
11 & $\mathrm{NA}$ & $\mathrm{NA}$ \\
12 & $\mathrm{NA}$ & $\mathrm{NA}$ \\
Pentamidine & $1.63 \pm 0.21$ & $2.18 \pm 0.25$ \\
Amphotericin B & $0.27 \pm 0.02$ & $0.33 \pm 0.03$
\end{tabular}

aValues are means \pm s.d. of duplicate observations.

bNot active up to the highest concentration $\left(40 \mu \mathrm{g} \mathrm{ml}^{-1}\right)$ tested.

by the lack of activity of derivatives $\mathbf{1 0}$ and $\mathbf{1 1}$ wherein the methylene group and the lactone carbonyl of the furanone ring were converted to a dihydrofuranone ring. Finally, the hydroxy group (at C-4) of the 1-methyl-4-hydroxypentyl residue in inuloxin $\mathrm{D}$ also seems to be a critical determinant for the antileishmanial property; the corresponding acetyl derivative $\mathbf{1 2}$ demonstrated a large decrease in the activity compared to the parent compound. These results are in full agreement with those recently obtained from the structureactivity relationship study on inuloxins A-D and derivative 10 tested for their inhibitory activity of seed germination of two parasitic plant broomrape (Orobanche crenata) and field dodder (Cuscuta campestris). ${ }^{11}$

In summary, in vitro evaluation of the twelve (five naturally occurring and seven hemisynthethic inuloxin derivatives) compounds tested, inuloxins $\mathrm{A}, \mathrm{C}$, and $\mathrm{D}$ exhibited strong activity against the parasitic protozoan $L$. donovani, with inuloxin A being the most active. Structure-activity analysis indicates that a furanone ring with an exocyclic methylene group at C-11 is a critical structural feature for the antileishmanial activity. These compounds may be promising new antileishmanial drug leads.

\section{EXPERIMENTAL PROCEDURE}

Elemental analyses were performed with a Fison (Walthman, MA, USA) Elemental Analyzer EA 1108 CHNS-O; IR spectra were recorded as glassy film on a Perkin-Elmer Spectrum (Norwalk, CT, USA) One FT-IR Spectrometer; UV spectra were recorded in $\mathrm{MeOH}$ solution on a Perkin-Elmer Lambda 25 UV/Visible spectrophotometer; ${ }^{1} \mathrm{H}$ NMR spectra were recorded at 400 or $100 \mathrm{MHz}$, in $\mathrm{CDCl}_{3}$, on Bruker spectrometers (Karlsruhe, Germany). The same solvent was used as internal standard; ESI- and APCI-MS spectra were recorded on Agilent Technologies (Milan, Italy) 6120 Quadrupole LC/MS instruments. Analytical and preparative thin layer chromatography (TLC) were performed on silica gel (Kieselgel 60, $\mathrm{F}_{254}, 0.25$ and $0.5 \mathrm{~mm}$, respectively; Merck, Darmstadt, Germany) plates; the spots were visualized by exposure to UV light or by spraying with $10 \% \mathrm{H}_{2} \mathrm{SO}_{4}$ in $\mathrm{MeOH}$ and then $5 \%$ phosphomolybdic acid in $\mathrm{EtOH}$, followed by heating at $110^{\circ} \mathrm{C}$ for $10 \mathrm{~min}$. Column chromatography was performed with silica gel (Kiesegel 60, 0.0063-0.200 mm, Merck).

The aerial parts of Inula viscosa plants were collected fresh in Italy. A voucher specimen was deposited at the Istituto di Scienze delle Produzioni Alimentari, CNR, Bari, Italy. After harvesting, leaves were detached from the stems and dried in a ventilated oven at $50^{\circ} \mathrm{C}$ for two days. The plant material was then ground to obtain a fine powder by using a lab mill, and packaged in plastic bags under vacuum until its use. Plant material $(400 \mathrm{~g})$ was extracted as reported previously. ${ }^{11}$ The organic extracts were combined, dehydrated $\left(\mathrm{Na}_{2} \mathrm{SO}_{4}\right)$ and evaporated under reduced pressure, giving a brown-red oily residue $(6.12 \mathrm{~g})$. Subsequent purification steps led to the isolation of inuloxins A-D (1-4) as described previously. ${ }^{11}$

\section{3,O,11,13-Tetrahydroinuloxin A (6 and 7)}

$\mathrm{NaBH}_{4}(16 \mathrm{mg}, 0.42 \mathrm{mmol})$ was added to inuloxin A $(1,25 \mathrm{mg}, 0.10 \mathrm{mmol})$ dissolved in $\mathrm{MeOH}(1 \mathrm{ml})$. The reaction was stopped after $2 \mathrm{~h}$ by neutralization with $1 \mathrm{M} \mathrm{HCl}(1 \mathrm{ml})$. The solution was extracted with ethyl acetate $(3 \times 10 \mathrm{ml})$ and the organic extracts combined, dried $\left(\mathrm{Na}_{2} \mathrm{SO}_{4}\right)$ and filtered. The residue $\left(33 \mathrm{mg}\right.$ ) was purified by TLC (silica gel, developing solvent $\mathrm{CHCl}_{3}-i-\mathrm{PrOH}$ 95:5), to give derivative $6\left(10 \mathrm{mg}, 0.040 \mathrm{mmol}, 40 \%, R_{\mathrm{f}} 0.44\right)$ and $7(10.4 \mathrm{mg}$, $0.041 \mathrm{mmol}, 40 \%, R_{\mathrm{f}} 0.50$ ) as homogeneous yellow amorphous solid. 6 had IR $v_{\text {max }}: 3450,1755,1655,1456,1196 \mathrm{~cm}^{-1}$; UV $\lambda_{\max }<220 \mathrm{~nm}$; ${ }^{1} \mathrm{H}$ NMR, $\delta: 5.52$ (dd, $J=9.1$ and $8.2 \mathrm{~Hz}, 1 \mathrm{H}, \mathrm{H}-5) ; 4.62(\mathrm{~m}, 1 \mathrm{H}, \mathrm{H}-8) ; 3.79(\mathrm{~m}, 1 \mathrm{H}, \mathrm{H}-3) ; 2.78$ (quin, $J=7.6 \mathrm{~Hz}, 1 \mathrm{H}, \mathrm{H}-11), 2.67(\mathrm{~m}, 1 \mathrm{H}, \mathrm{H}-7) ; 2.37$ (m, 1H, H-10); 2.25 (m, 1H, H-6A); 2.23 (m, 1H, H-1A); 2.05 (m, 2H, $\left.\mathrm{H}_{2}-9\right) ; 1.92$ (m, 1H, H-6B); $1.88(\mathrm{~m}, 1 \mathrm{H}, \mathrm{H}-1 \mathrm{~B}) ; 1.50\left(\mathrm{~m}, 2 \mathrm{H}, \mathrm{H}_{2}-2\right) ; 1.20$ (d, J=7.6 Hz, $\left.3 \mathrm{H}, \mathrm{Me}-13\right) ; 1.15$ (s, 3H, Me-14); $1.16(\mathrm{~d}, J=8.0 \mathrm{~Hz}, 3 \mathrm{H}, \mathrm{Me}-15)$; ESI-MS (+) $\mathrm{m} / \mathrm{z}: 275$ $[\mathrm{M}+\mathrm{Na}]^{+}$; ESI-MS (-) m/z: $251[\mathrm{M}-\mathrm{H}]^{-}$; APCI-MS $(+), m / z: 253$ $[\mathrm{M}+\mathrm{H}]^{+}, 235\left[\mathrm{M}+\mathrm{H}-\mathrm{H}_{2} \mathrm{O}\right]^{+}$; elemental analysis: $\mathrm{C}, 71.42 ; \mathrm{H}, 9.52 ; \mathrm{O}$, 18.97 (calculated for $\mathrm{C}_{15} \mathrm{H}_{24} \mathrm{O}_{3}, \mathrm{C}, 71.39 ; \mathrm{H}, 9.59 ; \mathrm{O}, 19.02$ ). 7 had IR $v_{\max }$ : $3452,1758,1661,1460,1170 \mathrm{~cm}^{-1}$; UV $\lambda_{\max }<220 \mathrm{~nm}$; ${ }^{1} \mathrm{H}$ NMR, $\delta: 5.43$ (dd, $J=7.6$ and $6.4 \mathrm{~Hz}, 1 \mathrm{H}, \mathrm{H}-5), 4.48(\mathrm{~m}, 1 \mathrm{H}, \mathrm{H}-8), 3.79(\mathrm{~m}, 1 \mathrm{H}, \mathrm{H}-3), 2.41$ (quin, $J=7.2 \mathrm{~Hz}, 1 \mathrm{H}, \mathrm{H}-11), 2.28(\mathrm{~m}, 1 \mathrm{H}, \mathrm{H}-10), 2.27$ (m, $1 \mathrm{H}, \mathrm{H}-7), 2.16-1.88$ (m, 2H, $\left.\mathrm{H}_{2}-6\right)$, 2.07-1.94 (m, 2H, $\left.\mathrm{H}_{2}-1\right), 1.98\left(\mathrm{~m}, 2 \mathrm{H}, \mathrm{H}_{2}-9\right), 1.56(\mathrm{~m}, 2 \mathrm{H}$, $\left.\mathrm{H}_{2}-2\right), 1.22$ (d, J=7.2 Hz, 3H, Me-13), 1.21 (s, 3H, Me-14), 1.17 $(\mathrm{d}, J=6.8 \mathrm{~Hz}, 3 \mathrm{H}, \mathrm{Me}-15)$; ESI-MS $(+) m / z: 275[\mathrm{M}+\mathrm{Na}]^{+}$; ESI-MS $(-) \quad m / z 251[\mathrm{M}-\mathrm{H}]^{+} ;$APCI-MS $(+), \quad m / z: 253 \quad\left[\mathrm{M}^{+} \mathrm{H}\right]^{+}, \quad 235$ $\left[\mathrm{M}+\mathrm{H}-\mathrm{H}_{2} \mathrm{O}\right]^{+}$; elemental analysis: $\mathrm{C}, 71.44 ; \mathrm{H}, 9.47 ; \mathrm{O}, 19.09$ (calculated for $\left.\mathrm{C}_{15} \mathrm{H}_{24} \mathrm{O}_{3}, \mathrm{C}, 71.39 ; \mathrm{H}, 9.59 ; \mathrm{O}, 19.02\right)$.

3-O-Acetyl Derivatives of 3,O,11,13-Tetrahydroinuloxin A (8 and 9) A total of $5 \mathrm{mg}$ of $6(0.020 \mathrm{mmol})$ was acetylated with pyridine $(80 \mu \mathrm{l}$, $0.99 \mathrm{mmol})$ and $\mathrm{Ac}_{2} \mathrm{O}(80 \mu \mathrm{l}, 0.85 \mathrm{mmol})$ at room temperature for $12 \mathrm{~h}$. The reaction was stopped by addition of $\mathrm{MeOH}$, and the azeotrope obtained by addition of benzene was evaporated with $\mathrm{N}_{2}$ stream. The oily residue $(7.7 \mathrm{mg})$ was purified by preparative TLC eluted with $\mathrm{CHCl}_{3}-i-\mathrm{PrOH}$ (97:3) giving derivative $8\left(5 \mathrm{mg}, 0.017 \mathrm{mmol}, 85 \%, R_{\mathrm{f}} 0.44\right)$ as homogeneous yellow amorphous solid. 8 had IR $v_{\max }: 1786,1753,1665,1453,1150 \mathrm{~cm}^{-1}$; UV $\lambda_{\max }<220 \mathrm{~nm} ;{ }^{1} \mathrm{H}$ NMR, differed from 6 for the following signals: $\delta 5.47$ (br. $\mathrm{t}, J=8.4 \mathrm{~Hz}, 1 \mathrm{H}, \mathrm{H}-3), 4.86(\mathrm{~m}, 1 \mathrm{H}, \mathrm{H}-5), 2.02(\mathrm{~s}, \mathrm{MeCO})$. ESI-MS (+) $\mathrm{m} / \mathrm{z}$ $317[\mathrm{M}+\mathrm{Na}]^{+}, 295[\mathrm{M}+\mathrm{H}]^{+}$; elemental analysis: $\mathrm{C}, 69.29 ; \mathrm{H}, 9.02 ; \mathrm{O}, 21.65$ (calcd for $\mathrm{C}_{17} \mathrm{H}_{26} \mathrm{O}_{4}, \mathrm{C}, 69.36 ; \mathrm{H}, 8.90 ; \mathrm{O}, 21.74$ ). Similarly $5 \mathrm{mg}$ of 7 $(0.020 \mathrm{mmol})$ was converted into the corresponding 3-O-acetyl derivative 9 using the same conditions and workup reaction used to convert 6 into 8 . The oily residue $(7.5 \mathrm{mg})$ was purified by preparative TLC eluted with $\mathrm{CHCl}_{3}-i$ PrOH (97:3) giving derivative $9\left(4.7 \mathrm{mg}, 0.016 \mathrm{mmol}, 80 \%, R_{\mathrm{f}} 0.45\right)$ as homogeneous yellow amorphous solid. 9 had IR $v_{\max }$ : 1784, 1756, 1662, $1457,1146 \mathrm{~cm}^{-1}$; UV $\lambda_{\max }<220 \mathrm{~nm}$; ${ }^{1} \mathrm{H} \mathrm{NMR}$, differed from that of 7 for the following signals: $\delta 5.41$ (br. dd, $J=8.0$ and $10 \mathrm{~Hz}, 1 \mathrm{H}, \mathrm{H}-3$ ), 4.88 (br. dd, $J=5.2$ and $6.4 \mathrm{~Hz}, 1 \mathrm{H}, \mathrm{H}-5), 2.05$ (s, MeCO); ESI-MS (+) $\mathrm{m} / z 317$ $[\mathrm{M}+\mathrm{Na}]^{+}, 295[\mathrm{M}+\mathrm{H}]^{+}$; elemental analysis: $\mathrm{C}, 69.40 ; \mathrm{H}, 8.82 ; \mathrm{O}, 21.81$ (calcd for $\mathrm{C}_{17} \mathrm{H}_{26} \mathrm{O}_{4}, \mathrm{C}, 69.36 ; \mathrm{H}, 8.90 ; \mathrm{O}, 21.74$ ).

\section{Inuloxin A Derivative 10}

Inuloxin A was converted into $\mathbf{1 0}$ as previously reported. ${ }^{11}$

\section{Reaction of Inuloxin C with Diazomethane to Prepare Derivative 11}

An ethereal solution of diazomethane $(250 \mu \mathrm{l}, 8.3 \mathrm{mmol})$ was added to inuloxin $\mathrm{C}(3,13 \mathrm{mg}, 0.052 \mathrm{mmol})$, dissolved in $\mathrm{MeOH}(100 \mu \mathrm{l})$. The reaction was carried out for $1 \mathrm{~h}$ at room temperature, and then stopped by evaporation under $\mathrm{N}_{2}$ stream. The residue ( $15 \mathrm{mg}$ ) was purified by preparative TLC using 
$n$-hexane-EtOAc (6:4), yielding the derivative 11 as an oily solid $(11.2 \mathrm{mg}$, $\left.0.043 \mathrm{mmol}, 83 \%, R_{\mathrm{f}} 0.23\right) .11$ had IR $v_{\max }: 3430,1699,1662,1549$; UV $\lambda_{\max }$ $<220 \mathrm{~nm} ;{ }^{1} \mathrm{H}$ NMR, differed from that of $\mathbf{3}$ for the following signals: $\delta 5.22$ (ddd, $J=10.2,5.6$ and $4.7 \mathrm{~Hz}, 1 \mathrm{H}, \mathrm{H}-8) ; 5.07(\mathrm{~s}, 1 \mathrm{H}, \mathrm{H}-15 \mathrm{~A}) ; 4.99(\mathrm{~s}, 1 \mathrm{H}$, H-15B), 4.78 (ddd, $J=10.0,9.6$ and $5.2 \mathrm{~Hz}, 1 \mathrm{H}, \mathrm{H}-16 \mathrm{~A}$ ), 4.64 (ddd, $J=10.0$, 8.4 and $7.2 \mathrm{~Hz}, 1 \mathrm{H}, \mathrm{H}-16 \mathrm{~B}$ ), 1.79 (ddd, $J=15.0,8.4$ and $5.2 \mathrm{~Hz}, 1 \mathrm{H}, \mathrm{H}-13 \mathrm{~A}$ ), 1.69 (ddd, $J=15.0,9.6$ and $7.2 \mathrm{~Hz}, 1 \mathrm{H}, \mathrm{H}-13 \mathrm{~B}$ ); ESI-MS $(+) \mathrm{m} / z: 283$ $[\mathrm{M}+\mathrm{Na}]^{+}, 261[\mathrm{M}+\mathrm{H}]^{+}$; elemental analysis: $\mathrm{C}, 73.32 ; \mathrm{H}, 8.39 ; \mathrm{O}, 18.22$ (calculated for $\mathrm{C}_{16} \mathrm{H}_{22} \mathrm{O}_{3}, \mathrm{C}, 73.25 ; \mathrm{H}, 8.45 ; \mathrm{O}, 18.30$ ).

\section{4-O-Acetylinuloxin D (12)}

Inuloxin $\mathrm{D}(4,10 \mathrm{mg}, 0.04 \mathrm{mmol})$ was acetylated with pyridine $(50 \mu \mathrm{l}$, $0.62 \mathrm{mmol})$ and $\mathrm{Ac}_{2} \mathrm{O}(50 \mu \mathrm{l}, 0.53 \mathrm{mmol})$ at room temperature. The reaction workup was the same as reported above to convert 6 into 8 . The oily residue $\left(12 \mathrm{mg}\right.$ ) was purified by preparative TLC using $\mathrm{CHCl}_{3}-i-\mathrm{PrOH} 95: 5$ giving 4-O-acetyl derivate $(12)$ as an oily compound $\left(9.0 \mathrm{mg}, 0.031 \mathrm{mmol}, 78 \%, R_{\mathrm{f}}\right.$ 0.82 ). Derivative 12 had IR $v_{\max }: 1780,1752,1654,1129$; UV: $\lambda_{\max } \mathrm{nm}(\log \varepsilon)$ 259 (1.06); ${ }^{1} \mathrm{H}$ NMR, differed from that of 4 for the following signals, $\delta 5.44$ (dd, $J=8.8$ and $5.2 \mathrm{~Hz}, 1 \mathrm{H}, \mathrm{H}-5) ; 4.86(\mathrm{~m}, 1 \mathrm{H}, \mathrm{H}-4) ; 4.64$ (ddd, $J=11.6,8.6$ and $2.4 \mathrm{~Hz}, 1 \mathrm{H}, \mathrm{H}-8) ; 2.04$ (s, MeCO), 1.24 (d, $J=6.0,3 \mathrm{H}$, Me-15). ESI-MS $(+) \mathrm{m} / z: 315[\mathrm{M}+\mathrm{Na}]^{+}$; elemental analysis: $\mathrm{C}, 69.78 ; \mathrm{H}, 8.20 ; \mathrm{O}, 21.94$ (calculated for $\mathrm{C}_{17} \mathrm{H}_{24} \mathrm{O}_{4}, \mathrm{C}, 69.84 ; \mathrm{H}, 8.27 ; \mathrm{O}, 21.89$ ).

\section{Antileishmanial Assay}

The in vitro antileishmanial assay was done on a culture of $L$. donovani promastigotes by the Alamar Blue assay. ${ }^{14}$ The promastigotes culture was maintained at $26^{\circ} \mathrm{C}$ in RPMI $1640 \mathrm{pH} 7.4$ with $10 \%$ FBS. In a 96-well microplate, the samples with appropriate dilution were added to the leishmania promastigotes culture $\left(2 \times 10^{6} \mathrm{cell} \mathrm{ml}{ }^{-1}\right)$. The compounds were tested at six concentrations ranging from 0.0128 to $40 \mu \mathrm{g} \mathrm{ml}^{-1}$. The plates were incubated at $26^{\circ} \mathrm{C}$ for $72 \mathrm{~h}$ and the growth of leishmania promastigotes was determined by the Alamar Blue assay as described earlier. ${ }^{15} \mathrm{IC}_{50}$ and $\mathrm{IC}_{90}$ values were computed from the dose response curves (see Table 1).

\section{ACKNOWLEDGEMENTS}

We thank Dr Maurizio Vurro, Instituto di Scienze delle Produzioni Alimentari, CNR, Bari, Italy for providing the plant material. We thank Dr Melissa Jacob for the general screening for antimicrobial activity of the compounds. We also thank Ms Gloria Hervey for technical help. This research was supported in part by ARIMNET subprogram MEDILEG from the European Union, Call 2011. Dr Babu L. Tekwani is supported by US Department of Defense CDMRP, grant No. W81XWH-09-2-0093 and USDA ARS Specific Cooperative Agreement No. 58-6408-1-603. Professor A. Evidente is also associated with the Instituto di Chimica Biomolecolare, CNR, Pozzuoli, Italy.

1 Desjeux, P. Leishmaniasis: public health aspects and control. Clin. Dermatol. 14, 417-423 (1996).

2 Myler, P. J. \& Fasel, N. Leishmania: After the Genome 3321. pages (Caister Academic Press Linton, Cambridgeshire, UK, 2008).

3 Desjeux, P. The increase in risk factors for leishmaniasis worldwide. Trans. R. Soc. Trop. Med. Hyg. 95, 239-243 (2001).

4 González, U. et al. Interventions for American cutaneous and mucocutaneous leishmaniasis. Cochrane Database Syst. Rev. 2, CD004834 (2009).

5 Navin, T. R. et al. Placebo controlled clinical trial of sodium stibogluconate (pentostam) versus ketoconazole fror treating cutaneous leishmaniasis in Guatemala. J. Infect. Dis. 165, 528-534 (1992).

6 Soto, J. et al. Treatment of American cutaneous leishmaniasis with miltefosine, an oral agent. Clin. Infect. Dis. 33, E57-E61 (2001).

7 Arevalo, J. et al. Influence of Leishmania (Viannia) species on the response to antimonial treatment in patients with American tegumentary leishmaniasis. J. Infect. Dis. 195, 1846-1851 (2007).

8 Oliveira, L. F. et al. Systematic review of the adverse effects of cutaneous leishmaniasis treatment in the New World. Acta Trop. 118, 87-96 (2011).

9 Sundar, S. et al. Short-course paromomycin treatment of visceral leishmaniasis in India: 14-day vs 21-day treatment. Clin. Infect. Dis. 49, 850-851 (2009).

10 Badaro, R. et al. Immunotheraphy for drug-refractory mucosal leihmanaisis. J. Infect. Dis. 194, 1151-1159 (2006)

11 Andolfi, A. et al. Inuloxins A-D, phytotoxic bi- and tri-cyclic sesquiterpene lactones produced by Inula viscosa: potential for broomrapes and field dodder management. Phytochemistry 86, 112-120 (2013).

12 Chang, K. P. \& Dwyer, D. M. Multiplication of a human parasite (Leishmania donovani) in phagolysosomes of hamster macrophages in vitro. Science 193, 678-680 (1976).

13 Schmidt, T. J. et al. Quantitative structure-antiprotozoal activity relationship of sesquiterpene lactones. Molecules 14, 2062-2076 (2009).

14 Mikus, J. \& Steverding, D. A simple colorimetric method to screen drug cytotoxicity against Leishmania using the dye Alamar Blue. Parasitol. Int. 48, 265-269 (2000).

15 Pieroni, M. et al. Synthesis activity relationships of lansine analogues as antileishmanial agents. Chem. Med. Chem. 7, 1895-1900 (2012). 